University of Wollongong

Research Online

Faculty of Social Sciences - Papers (Archive) Faculty of Arts, Social Sciences \& Humanities

2017

The environmental implications of multigenerational living: Are larger

households also greener households?

Natascha Klocker

University of Wollongong, natascha@uow.edu.au

Christopher R. Gibson

University of Wollongong, cgibson@uow.edu.au

Erin Borger

University of Wollongong, eb094@uow.edu.au

Follow this and additional works at: https://ro.uow.edu.au/sspapers

Part of the Education Commons, and the Social and Behavioral Sciences Commons

Research Online is the open access institutional repository for the University of Wollongong. For further information contact the UOW Library: research-pubs@uow.edu.au 


\title{
The environmental implications of multigenerational living: Are larger households also greener households?
}

\author{
Abstract \\ Multigenerational family households rarely form out of environmental concern - or an intentional desire to \\ be 'green'. More typically, they form because of financial pressures, caring responsibi1ities or to \\ accommodate disruptions in extended families such as divorce or unemployment. Yet, they offer \\ important, innate opportunities to reduce resource consumption. On a per capita basis, household size is \\ inversely related to resource consumption and waste production. By housing more family members under \\ one roof, multigenerational family living presents unheralded opportunities to save energy, water, building \\ materials and land. Our ethnographic research with multigenerational family households in Wollongong, \\ in the Illawarra region of southeastern Australia, explored the ways in which resources are consumed and \\ shared in their rhythms of everyday life. These families inadvertently reduced their consumption of \\ material resources by sharing space and everyday objects: white goods, furniture, cooking equipment, \\ electronics, clothing, books, food, swimming pools and more. Although these sharing practices were not \\ intentionally 'green', they nonetheless obviated the need for additional purchases to be made. At the same \\ time, these households were sites of environmental debate and intergenerational leaming. $01 \mathrm{der}$ \\ generations - while not identifying as environmentalists - sought to instil values of thrift among their \\ younger relatives. They wanted to pass their inadvertent - or unintentional - sustainabilities onto their \\ children and grandchildren. The term 'inadvertent sustainabilities' refers to practices not conceived with \\ sustainability in mind, but which are environmentally beneficial nonetheless. Some younger household \\ members, for their part, made persistent attempts to counter their parents' and grandparents' climate \\ change skepticism, and to promote intentionally sustainable practices and purchases. Multigenerational \\ family households thus provide fertile ground for the frugal (inadvertently 'green') practices and skills of \\ older generations, and the intentional environmentalism of younger generations, to collide and coalesce - \\ with profound implications for everyday domestic life. Throughout this chapter, we follow Blunt (2005) \\ and Reid et al. (2010) in defining a household as a social unit occupying a single place or space of \\ residence (the dwelling). Our definition of multigenerational family households is expansive. It includes \\ adult children who have remained in - or returned to -the parental home (with or without their own spouse \\ and children), and elderly parents living with one or more adult children. Additional relatives (whether \\ aunts, uncles, grandparents or cousins) may be'added on' to an existing nuclear family unit. Each of these \\ household configurations brings together related individuals in a manner distinct from single-parent or \\ nuclear family living arrangements that involve one or more parents and their dependent child(ren). In so \\ doing, they decrease the overall number of dwellings required to house an equivalent number of people. In \\ the remainder of this chapter, we provide detail around the innate environmental benefits of larger \\ households, before positioning our study within a broad body of cultural environmental research at the \\ household scale. After outlining our research methods, we present empirical evidence of two types of \\ sharing that take place in multigenerational family households - of space and material objects and more \\ important, of ideas, skills and knowledge. Multigenerational family households engender opportunities to \\ be inadvertently and deliberately 'green'. We conclude by taking our research findings to a further, \\ speculative, step: in a climate-changing world, these households also hold important and unexplored \\ potential for coping with environmental calamities.

\section{Disciplines} \\ Education | Social and Behavioral Sciences
}

\section{Publication Details}

Klocker, N., Gibson, C. \& Borger, E. (2017). The environmental implications of multigenerational living: Are larger households also greener households?. In E. Liu \& H. Easthope (Eds.), Multigenerational Family 
Living: Evidence and Policy Implications from Australia (pp. 160-177). Abingdon, United Kingdom: Routledge. 
Klocker, N., Gibson, C. and Borger, E. 2016 The environmental implications of multigenerational living: Are larger households also greener households? In E. Liu and $\mathrm{H}$. Easthope (eds) Multigenerational Family Living: Evidence and Policy Implications from Australia. Routledge, London and New York, pp. 160-177

http://dx.doi.org/10.4324/9781315596266

\section{Chapter 10}

\section{The Environmental Implications of Multigenerational Living: Are Larger Households also Greener Households?}

Natascha Klocker, Chris Gibson and Erin Borger

\section{Introduction}

Multigenerational family households rarely form out of environmental concern - or an intentional desire to be 'green.' More typically, they form because of financial pressures, caring responsibilities or to accommodate disruptions in extended families such as divorce or unemployment (Klocker et al. 2012). Yet they offer important, innate opportunities to reduce resource consumption. On a per capita basis, household size is inversely related to resource consumption and waste production (Liu et al. 2003). By housing more family members under one roof, multigenerational family living presents unheralded opportunities to save energy, water, building materials and land. Our ethnographic research with multigenerational family households in Wollongong, in the Illawarra region of south-eastern Australia, explored the ways in which resources are consumed and shared in their rhythms of everyday life. These families inadvertently reduced their consumption of material resources by sharing space and everyday objects: white goods, furniture, cooking equipment, electronics, clothing, books, food, swimming pools and more. While these sharing practices were not intentionally 'green,' they nonetheless obviated the need for additional purchases to be made.

At the same time, these households were sites of environmental debate and intergenerational learning. Older generations - while not identifying as environmentalists - sought to instil values of thrift amongst their younger relatives. They wanted to pass their inadvertent - or unintentional - sustainabilities onto their children and grandchildren. The term 'inadvertent sustainabilities' refers to practices not conceived with sustainability in mind, but which are 
environmentally beneficial nonetheless (Krueger and Agyeman 2005; Klocker et al. 2012). Some younger household members, for their part, made persistent attempts to counter their parents and grandparents' climate change scepticism, and to promote intentionally sustainable practices and purchases. Multigenerational family households thus provide fertile ground for the frugal (inadvertently 'green') practices and skills of older generations, and the intentional environmentalisms of younger generations, to collide and coalesce - with profound implications for everyday domestic life.

Throughout this chapter, we follow Blunt (2005) and Reid et al. (2010) in defining a household as a social unit occupying a single place or space of residence (the dwelling). Our definition of multigenerational family households is an expansive one. It includes adult children who have remained in - or returned to - the parental home (with or without their own spouse and children), and elderly parents living with one or more adult children. Additional relatives (whether aunts, uncles, grandparents or cousins) may be 'added on' to an existing nuclear family unit. Each of these household configurations brings together related individuals in a manner distinct from single-parent or nuclear family living arrangements that involve one or more parents and their dependent child/ren (see also Klocker et al. 2012). In so doing, they decrease the overall number of dwellings required to house an equivalent number of people.

In the remainder of this chapter, we first provide detail around the innate environmental benefits of larger households, before positioning our study within a broad body of cultural environmental research at the household scale. After outlining our research methods, we present empirical evidence of two types of sharing that take place in multigenerational family households - of space and material objects and importantly, of ideas, skills and knowledge. Multigenerational family households engender opportunities to be inadvertently and deliberately 'green.' We conclude by taking our research findings a further, speculative, step: in a climate-changing world, these households also hold important and unexplored potential for coping with environmental calamities.

\section{The Innate Environmental Benefits of Larger Households}

Taken at an aggregate level, larger households - those with more members - consume more resources (e.g. energy, water, food); they also produce more waste. Yet, on a per capita basis the inverse is true. Economies of scale are at work, meaning that households with more 
members typically consume fewer resources - and generate less waste - per person (e.g. Keilman 2003; Lenzen et al. 2004; Yu and Liu 2007). Individuals' ecological footprints decrease with increasing household size (Lenzen and Murray 2001). The multigenerational family households in our study contained an average of 4.3 occupants, well above the national average of 2.6 persons per household in 2011 (Australian Bureau of Statistics 2012).

A range of quantitative studies has demonstrated the significance of the above-mentioned inversion. In a provocative paper entitled The threat of small households, Keilman (2003) raised concern about declining household sizes, globally. Between 1970 and 2000, the average number of occupants per household decreased from 5.5 to 4.4 people in the Majority World (developing countries) and from 3.2 to 2.5 in the Minority World (developed countries). This trend compounds the demand for additional resources generated by population growth because opportunities to 'share space, home furnishings, transportation and energy' are reduced (Keilman 2003: 489; see also Liu et al. 2003). The magnitude of resource savings generated by cohabitation is not trivial. An early study conducted in the United States (US) found that two-person households consumed 17 per cent less energy per person than single-person households, while three-person households used one-third less energy per capita (O’Neill and Chen 2002). Yu and Liu (2007) found that divorced households in the US (which had fewer occupants than married households) spent 46 per cent and 56 per cent more on electricity and water per capita. This resulted in 73 billion kilowatt hours of additional electricity use, and 627 billion gallons of additional water use in the US in 2005 alone (Yu and Liu 2007). In Sydney, Australia, the Independent Pricing and Regulatory Tribunal (IPART 2010) found that households with five occupants consumed 2.1 megawatt hours of electricity per person, per year. This was less than half the amount used (per capita) in single-person households (5.6 megawatt hours per year). Similarly, households containing five or more people used around 54 kilolitres of water per person per annum, compared to 135 kilolitres in single-person households (IPART 2010; see also Lenzen et al. 2004). Similar economies of scale in relation to water use were reported in Zaragoza, Spain: single-person households consumed $0.1845 \mathrm{~m}^{3}$ (around $185 \mathrm{~L}$ ) of water per person, per day - but fourperson households used just over half that amount $\left(0.0999 \mathrm{~m}^{3}\right.$ or $100 \mathrm{~L}$ per person, per day; Arbués et al. 2010). And in an iconic case, in the area around the Wolong Nature Reserve (China), Liu et al. (2001) linked shrinking household sizes to increased fuel wood consumption, increased deforestation and thus habitat loss for giant pandas. 
By reducing the aggregate number of dwellings needed, larger multigenerational family households can also contribute to reduced demand for land and building materials. In relation to the first, Liu et al. (2003) argued that biodiversity conservation is threatened by the dual trend of increasing population and shrinking household sizes - which is causing the aggregate number of households to grow rapidly. The significance of these trends is particularly apparent in China. The Chinese population is projected to near 1.5 billion by 2030 , over which time the average household size is projected to drop to 2.2 people (from 3.5 in 2000, and 4.5 in 1985; Liu and Diamond 2005). Liu and Diamond (2005) found that declining household sizes alone would create 250 million additional households by 2030, even if the overall population size were to remain constant.

While on a lesser scale, these trends also matter in Australia. Here, one-quarter of households contain just one person (ABS 2012). Following current trends in living arrangements, and aggregate population growth, the number of households in Australia is projected to grow from 7.8 million in 2006 to 11.4 million in 2031 (ABS 2010). In Sydney, 770,000 more homes will be added over the next 25 years (Nicholls and Moore 2011), at least half of which are predicted to be built on greenfield sites (O’Neill and James 2014). Urban expansion threatens peri-urban farmland (Han 2013) and biodiversity (Smith 2015). In addition to reducing demand for space, multigenerational family households can also generate savings in building materials, as fewer dwellings are needed. This is significant due to the sizeable carbon emissions associated with construction. The steel, glass, concrete, wood, tiles and bricks (among others) that go into constructing a new dwelling carry the baggage of embodied energy consumption associated with their extraction, manufacture and transportation. According to Berners-Lee (2010) each new two-storey, two-bedroom cottage produces 80 tonnes of carbon dioxide equivalent $\left(\mathrm{CO}_{2} \mathrm{e}\right)$ emissions due to the embodied energy encapsulated in building materials ${ }^{1}$. Wright et al. (2009) provide a means of visualising this - one tonne of $\mathrm{CO}_{2} \mathrm{e}$ can be imagined as 10,000 garbage bags filled with carbon dioxide. Construction of the above-mentioned cottage thus generates the equivalent of 800,000 garbage bags. Based on these calculations, the 770,000 new homes needed in

\footnotetext{
${ }^{1}$ Berners-Lee (2010) based this calculation on a cottage of that size in Scotland. $\mathrm{CO}_{2} \mathrm{e}$ refers to the total climate change impact of all the greenhouse gases caused by an activity/thing (expressed in terms of the amount of carbon dioxide that would be needed to have the same impact).
} 
Sydney will produce 616 billion garbage bags filled with carbon dioxide through embedded emissions alone. Efforts to mitigate the cumulative environmental impacts of these trends both in terms of carbon emissions and habitat loss, ought to factor in the possibility of larger household sizes. Policymakers and planners could do more to promote the benefits of - and support the formation of - multigenerational family households.

\section{Cultural Environmental Research at the Household Scale}

Our own study - while inspired by the evidence outlined above - did not seek to replicate a quantitative investigation of carbon emissions in multigenerational family households. Instead, it was informed by a growing body of cultural environmental research undertaken at the household scale. We asked why multigenerational family households form, and for these families, what kinds of sustainability benefits stem from practices of sharing (objects and resources) in amongst the exigencies of everyday life. The economies of scale that operate in these typically larger households relate to the sharing of resources, but how such sharing occurs remains opaque in large quantitative datasets. Our research provides an opportunity to explore sharing in actually existing larger-than-average households. Here, we consider how multigenerational family living arrangements provide fertile ground for sharing, thus obviating the need for additional resource consumption.

In recent years, households - particularly those in the Minority World - have become a focal point for environmental policymaking. Policymakers expect householders - as self-regulating and purportedly rational consumers - to take responsibility for reducing their resource consumption and waste production (Hobson 2006; Gibson et al. 2011; Lane and GormanMurray 2011). Governments have provided funding and subsidies for home solar panels, insulation, smart meters, rainwater tanks, energy efficient lightbulbs and shower timers; and householders have been encouraged to reduce their waste (for instance, by recycling and using 'green' shopping bags) and to take public transport. Cultural environmental research has acknowledged the importance of households as logical sites for understanding the consumption of resources, and as a crucial scale of social organisation for pro-environmental behaviour (Reid et al. 2010; Gibson et al. 2013; Head et al. 2013). But such research has also troubled the often simplistic ways in which policymakers have conceived of households. 
A number of researchers have argued that environmental policies have failed to have their desired effect at the household scale, because they have not adequately considered "what happens inside the home' (Horne et al. 2011: 89; see also Hobson 2008; Gibson et al. 2013). Households are increasingly diverse - demographically, culturally, socioeconomically - and everyday life within households is comprised of complex internal politics, practices, social relations and attributes. The ways in which we consume water, energy and other resources is shaped by the rituals, rhythms, emotions, habits and routines of everyday life (Shove 2003; Maller 2011).

Dominant policy approaches to household sustainability have also come under scrutiny for limiting their focus to so-called pro-environmental behaviours - explicitly and intentionally 'green' practices (Hobson 2006; Klocker et al. 2012). But day-to-day domestic life is motivated by diverse sets of concerns, values, priorities, demands and pressures above and beyond being 'green' (Gibson et al. 2013). This helps to explain why householders' stated environmental concerns do not always translate into action, widely referred to as the "valueaction gap' (Kollmuss and Agyeman 2002). Cultural environmental research has shown that environmentally beneficial actions regularly emerge without an explicit desire to be 'green.' Inadvertent environmentalisms arise when actions that are undertaken for other reasons (such as saving money) generate positive environmental spin-offs. Hitchings et al. (2015) refer to the 'action-value opportunity' of inadvertent environmentalisms - such as frugal heating practices that are intended to save money, not the environment (see also Evans 2011). With this in mind, our research on multigenerational family households was open to a diverse range of environmentally beneficial practices, whether or not they were conceived with sustainability in mind. We sought to explore how multigenerational family households function on a day-to-day basis, and how their internal dynamics - the diverse assemblages of people, spaces and things of which they are comprised - build upon (or at times constrain) the innate environmental benefits of their living arrangements.

\section{Methods}

Our research was conducted in Wollongong, a medium-sized coastal city in Australia, located around 60 kilometres to the south of Sydney. Two key methods were used: semi-structured in-depth interviews with 17 participants from 10 multigenerational family households, and home tours. Participants were initially recruited via a prior quantitative survey conducted by 
researchers at the University of Wollongong's Australian Centre for Cultural Environmental Research (AUSCCER) ${ }^{2}$ and then via snowballing (see Klocker et al. 2012 for further detail). Home tours are an increasingly common method used by human geographers to learn about the rhythms of everyday life - offering deeper insights into participants' ways of living (Tolia-Kelly 2004). Together with semi-structured interviews, they provided insights into how material resources and spaces in the home were used and shared. Participants showed the interviewer around their homes to provide insights into their ways of living. Interviewees were also asked to discuss their motivations for living in a multigenerational family household, and about the highlights and challenges of so doing. While none of the study participants nominated environmental concern as a reason for their living arrangement, towards the end of interviews they were asked to consider whether they could see any environmental benefits related to their household structure. Relevant information about the households involved in the study is provided in Table 10.1.

\section{Table 10.1 Description of households involved in this study}

\begin{tabular}{|c|c|c|c|c|}
\hline $\begin{array}{l}\text { Interviewees } \\
\text { (name }^{\mathrm{a}} \text {, age) }\end{array}$ & $\begin{array}{l}\text { No. of } \\
\text { people }\end{array}$ & Family relationships & $\begin{array}{l}\text { Anticipated } \\
\text { duration }\end{array}$ & Housing tenure \\
\hline \multicolumn{5}{|l|}{ Living together } \\
\hline $\begin{array}{l}\text { Leanne }(\sim 40) \text {, } \\
\text { Jodi }(30) \text {, } \\
\text { Brooke }(23)\end{array}$ & 3 & $\begin{array}{l}\text { Adult daughter (Jodi) and } \\
\text { partner (Brooke) moved in } \\
\text { with Jodi's mother (Leanne) }\end{array}$ & Short-term & $\begin{array}{l}\text { Owner-occupied } \\
\text { (Leanne) }\end{array}$ \\
\hline Nathan $(\sim 40)$ & 5 & $\begin{array}{l}\text { Adult son (Nathan), his wife } \\
\text { and young son, moved in } \\
\text { with his mother and father }\end{array}$ & Short-term & $\begin{array}{l}\text { Owner-occupied } \\
\text { (Nathan's } \\
\text { parents) }\end{array}$ \\
\hline $\begin{array}{l}\text { Neil }(\sim 70) \text {, Anne } \\
(\sim 70)\end{array}$ & 3 & $\begin{array}{l}\text { Adult son moved in with } \\
\text { mother and father (Anne and } \\
\text { Neil) }\end{array}$ & Short-term & $\begin{array}{l}\text { Owner-occupied } \\
\text { (Neil and Anne) }\end{array}$ \\
\hline Alex (18) & 3 & Adult granddaughter (Alex) & Long-term & Owner-occupied \\
\hline
\end{tabular}

\footnotetext{
${ }^{2}$ The 'Tough times? Green times?' survey was conducted by researchers at AUSCCER in 2009. A sample of 1,443 responses was obtained via a random postal survey.
} 


$\begin{array}{llll} & \begin{array}{l}\text { continued living with } \\ \text { grandparents after her own } \\ \text { mother moved out }\end{array} & \begin{array}{l}\text { (Alex's } \\ \text { grandparents) }\end{array} \\ \text { Michael }(\sim 20) & 6 \quad \begin{array}{l}\text { Adult son (Michael) moved } \\ \text { in with mother and father, } \\ \text { plus his adult sister, her } \\ \text { husband and her young child }\end{array} & \text { Short-term } & \text { Owner-occupied } \\ & & \text { (Michael's } \\ & & \end{array}$

Living together but apart

\begin{tabular}{|c|c|c|c|c|}
\hline $\begin{array}{l}\text { Gail }(\sim 70), \\
\text { Gabrielle }(\sim 30)\end{array}$ & 4 & $\begin{array}{l}\text { Grandmother (Gail) moved in } \\
\text { with adult daughter } \\
\text { (Gabrielle), son-in-law and } \\
\text { granddaughter }\end{array}$ & Long-term & $\begin{array}{l}\text { Owner-occupied } \\
\text { (Gabrielle and } \\
\text { husband) }\end{array}$ \\
\hline $\begin{array}{l}\text { Wendy }(\sim 40) \text {, } \\
\text { Wes }(-40)\end{array}$ & 3 & $\begin{array}{l}\text { Mother moved in with adult } \\
\text { daughter (Wendy) and son- } \\
\text { in-law (Wes) }\end{array}$ & Long-term & $\begin{array}{l}\text { Owner-occupied } \\
\text { (Wendy and } \\
\text { Wes) }\end{array}$ \\
\hline $\begin{array}{l}\text { Pauline ( } 50) \text {, } \\
\text { Melissa }(23)\end{array}$ & 5 & $\begin{array}{l}\text { Adult daughter (Melissa) } \\
\text { with young child moved in } \\
\text { with mother (Pauline) and } \\
\text { two adult sisters }\end{array}$ & Long-term & Renting \\
\hline Marion $(\sim 60)$ & 6 & $\begin{array}{l}\text { Adult daughter, her husband } \\
\text { and two young children } \\
\text { moved in with mother } \\
\text { (Marion) and father }\end{array}$ & Long-term & $\begin{array}{l}\text { Owner-occupied } \\
\text { (Marion and } \\
\text { husband) }\end{array}$ \\
\hline $\begin{array}{l}\text { Theresa (23), } \\
\text { Marissa (20) }\end{array}$ & 5 & $\begin{array}{l}\text { Two adult daughters (Theresa } \\
\text { and Marissa) living with } \\
\text { mother and grandparents }\end{array}$ & Long-term & $\begin{array}{l}\text { Owner-occupied } \\
\text { (grandparents) }\end{array}$ \\
\hline
\end{tabular}

${ }^{\mathrm{a}}$ Pseudonyms have been adopted where requested. Table adapted from Klocker et al. (2012).

Our interviewees were primarily female (13 of 17), but offered a multigenerational perspective, being aged between 18 and 70 years. Our sample did not aim to be representative of Australia's socioeconomic and cultural diversity, but instead sought to provide insights into the nuances of everyday life in multigenerational family households in ways that could shed further light on the environmental implications of these living arrangements. Some of the families involved in our study were low-income and others comfortably middle-income; 
five had migrant (Italian or Filipino) backgrounds. All but one of the dwellings was owneroccupied. The households involved in the study varied in size, from three to six occupants (with an average of 4.3). All exceeded the national average of 2.6 persons per household (ABS 2012).

The 10 multigenerational family households broadly fell into two (partially overlapping) categories: elderly parents who could not (or did not want to) live alone and therefore moved in with their adult children; and parents of young children who struggled to balance paid work and caring responsibilities. The latter typically moved in with their own parents to 'get back on their feet' financially or emotionally following marriage breakdown, a period of study or overseas travel, and/or due to the pressures of single-parenting. In both scenarios, family members made an intentional decision to live together. Bringing family members together under one roof provided invaluable support and opportunities to care for one another without needing to jump in the car.

Two different modes of multigenerational living were associated with these two categories. When an adult child moved in with his or her parents, the living arrangement was generally intended to be short in duration. These multigenerational families tended to live in standard dwellings, where they shared communal living spaces and activities. In Klocker et al. (2012), and in Table 10.1, we have referred to these families as 'living together.' When elderly parents moved in with their adult children, the multigenerational living arrangement was generally understood as a longer-term scenario. Under such circumstances, multigenerational living was made manageable by dividing the dwelling into separate living spaces. This mode of living was influenced by a culturally driven predilection for privacy and independence afforded by space. These families ostensibly lived under one roof, but they occupied selfcontained areas and were able to live relatively independently. We have referred to them as 'living together but apart.' Five of the participating households fell into each mode.

\section{Inadvertent Environmentalisms: Sharing Space, Sharing Stuff}

On the surface, those families that we classified as 'living together' might be expected to be more sustainable - because they shared household spaces to a greater extent, especially kitchens and living rooms (bathrooms and bedrooms were rarely shared across family units, irrespective of the mode of living adopted). However, as explained below, sharing was a common feature of everyday life in both household types. Importantly, the separation of 
spaces in households that were 'living together but apart' made multigenerational living palatable as a longer-term arrangement, because it allowed the household members involved to fulfil a culturally-ingrained need for privacy and independence. This way of living may have (in some respects) reduced the environmental gains of multigenerational family living but by making it durable, the gains that were realised would extend over many more years.

Households that were 'living together' typically shopped and cooked communally - and thus saved on transport costs and fuel consumption, as well as the energy used by cooking (Berners-Lee 2011). Shared living spaces also raise the attendant benefit of reducing electricity use - for instance, by lighting and heating/cooling one living room instead of two. That being said, some family members who had separate living spaces made an effort to share heating and cooling anyway. Gabrielle noted that her mother (Gail's) separate living space did not get heated during the day because, 'Mum can come up here if it's a particularly cold day, and in summer if it's one of those really boiling hot days then Mum sits up here with us with the aircon on.' While household spaces (and attendant activities) were typically shared to a greater extent in households that were 'living together,' material objects - the stuff of everyday life - were shared abundantly in both household types. Sandwich toasters, pasta cookers, spices and sauces, pyrex dishes, books, DVDs, furniture, clothing, vacuum cleaners, washing machines and clothes dryers were all widely shared.

Leanne noted that she purchased clothes less regularly, after her adult daughter Jodi moved in: 'I'll come and try Jodi's on and then I'll go back to the shop if I can't find anything.' The women living in Pauline's household also regularly shared clothing: 'Melissa and I would often share clothes. Megan and Patricia [sisters] share. So it does the rounds... The girls can't see the point in buying something that they will only wear once or twice.' Leftover food was also passed within and across both household types, thus reducing food waste. Gardens and swimming pools (where present) were shared irrespective of the mode of living adopted thus reducing water use, a particularly important outcome given recurrent water shortages in south-eastern Australia (Askew and McGuirk 2004). All of these seemingly minor and trivial acts of sharing contribute to a cumulative reduction in material consumption. While sharing also occurs amongst family members who live in separate dwellings - the ease of sharing in multigenerational family households is enhanced by proximity (being able to run upstairs or downstairs just before dinner to grab a bottle of soy sauce; or a dress before heading out for the night). Household members in these settings are able to share stuff, without needing to get in the car (and use fuel) to do so. 
Amidst all of this sharing, it is worth noting that cars, televisions and computers were rarely shared - irrespective of the mode of living adopted. The cultural value placed on independence and freedom (of viewing choices and movement), made replication of these items non-negotiable. As noted by Michael in relation to television and computer use: 'I think that it is a crucial thing when it comes to your personal space, is having that thing you can watch where you can switch your mind off from everything that's happening.' Importantly, while our households owned multiple cars, multigenerational living meant that they had to drive them less - they no longer needed to travel by car to care for or visit family members who were under the same roof. Wendy cared for her elderly mother and noted: 'before we moved in together...I spent a big chunk of time driving up and down...that doesn't happen now.' When it was convenient, family members also shared trips - as noted by Gabrielle: 'If Mum was in a house on her own, she would quite often take her car to go to the beach...whereas we go together now.' Theresa and Marissa reported combining their own grocery shopping trips with those of their grandparents.

Several study participants initially appeared to be taken by surprise when asked whether multigenerational family living offered opportunities to be more environmentally sustainable - they had not given this possibility prior thought. However, they were quite quickly able to identify important gains made through this living arrangement. Nathan (whose own multigenerational family household was recently disbanded) commented:

[W] are using more energy in separate houses than when we were in one house...If we were still living at my parents' house, that's one less T.V., that's one less light that's on, that's one less heater that's on, because we'd be sharing theirs.

For Wendy, fuel savings were 'probably the biggest thing,' while Gabrielle was able to identify a whole host of ways in which multigenerational family living reduces consumption:

Just because there's not a whole other house operating...if you're running your own whole house, it's a lot less sustainable than living in part of someone else's house. And we'll quite often do stuff together [saving fuel]...Even your garden, if you were looking after your own garden you would be watering that...we just have the one garden...[also] the heating and electricity and the lights. You've got to do your washing...you would be doing half loads...it just seems intuitive. 
In the following section, we consider how sets of knowledge, skills and values can also be shared across generations in multigenerational family households, in ways that may generate environmentally-beneficial outcomes.

\section{Multigenerational Households: Sharing Ideas, Skills and Knowledge}

Generations 'represent a distinct, temporally located cultural field' characterised by taste, values and dispositions shaped by popular culture, social norms and the socioeconomic and political circumstances of individuals' formative years (Jones et al. 2009: 101; see also Vanderbeck 2007; Stanes et al. 2015). Individuals who were born within the same broad time period often share important experiences 'in their maturation and socialisation' (Büttner and Grübler 1995: 116). The Silent Generation (aged around 65 or older, at the time of writing) grew up during the Great Depression, and also the rationing of World War II. They are widely identified as a thrifty and frugal generation (Stanes et al. 2015). Amongst our householders, Nathan spent a great deal of time discussing his father's thrifty nature:

Because they're on a fixed income, they're pensioners and so they can't get everything they want. That's partly why he is so thrifty, then again he's always been thrifty...he comes from a family of nine brothers and sisters and his mother never worked so his father worked at the Steelworks... When he was growing up, when it came to bath time...they would say, you would have a bath in the Sydney Morning Herald [newspaper]. You know, the Sydney Morning Herald is large, and the time it took for the Sydney Morning Herald to burn was how long the hot water lasted, and the bathtub was heated underneath. They all shared the same water. He left school at 15, because his family didn't have the money to send him on.

Nathan acknowledged his parents' frugality as a form of environmentalism:

Probably what motivates them more for shorter showers is the cost. Although they are probably old school environmental actually. Having long showers is a waste of water so they wouldn't be doing it purely out of being environmentally friendly, but they would be doing it because they don't like waste [emphasis added].

At the opposite end of the generational spectrum, Generation Y (aged around 18 to early 30s at the time of writing) has been typecast as a consumer generation. Despite evidence that young adults are environmentally-informed and concerned, they have been widely criticised 
for extravagance and throw-away consumerism, with attendant implications for resource consumption (Bentley et al. 2004; Autio et al. 2009; Percy-Smith and Burns 2013). While these stark generational stereotypes demand scrutiny (Stanes et al. 2015), the presence of multiple generations under one roof provides important opportunities for intergenerational learning (c.f. Strengers and Maller 2012). This was certainly evident in the households that participated in our study. On the one hand, older generations sought to instil their inadvertently 'green' behaviours upon younger generations, by being critical of waste and excess consumption. On the other hand, some younger household members actively sought to convince their co-habiting older relatives of their environmental values and knowledge. Either way, multigenerational family households provided fertile ground for the exchange of diverse sets of knowledge, values and skills. 'Green' domestic practices can be fostered via intergenerational effort and flows of encouragement: different generations bring 'diverse environmental skills to the table' (Stanes and Klocker 2016).

Evidence of parents and grandparents exerting influence over their children and grandchildren's consumption practices was abundant in the households involved in our study. In all cases, interviewees asserted that such efforts were motivated more by thrift and financial imperatives than environmental concern. Gabrielle, who described herself as fairly frugal, felt further compelled to avoid unnecessary purchases with her mother living in the same house:

I think, through my whole life it's been Mum's influence because we've always shopped at op shops... I always have trouble telling people when I've bought something new. I always feel like I shouldn't have bought something new [laughter]...I would have felt that...coming home to Frank [husband] and saying that I bought something new, I say 'but it was on sale, I've needed it for a long time' [laughter]. But quite possibly more with Mum here...

Nathan's wife was sensitive to his parents' criticisms when purchasing expensive, out-ofseason fruit or vegetables: 'he'll [Nathan's father] question her on why she bought it and would say "oh you shouldn't have done that. That's too expensive."' Marissa and Theresa were pressured by their grandmother to avoid throwing out leftover food, and Gabrielle was more careful to avoid food waste with her mother (Gail) in the house:

Gail: If they've got pasta leftover, I just say, 'Don't throw the pasta out I'll eat it.' 
Gabrielle: And that paid off because Frank [husband] was going to chuck out pasta two nights ago and I said, 'No mum wants us to keep it.' And he's got it for lunch today [laughter].

Leanne dissuaded her daughter Jodi, and Jodi's partner Brooke, from using the air conditioner unless it was absolutely necessary:

[T]here were a few days that...you'd [Jodi and Brooke] come home and it'd be like, 'How come you don't have the air conditioning on?', and I was like, 'well it's not really necessary.' You know, with like the windows open and stuff like that. And plus we've got the overhead fans so that makes a bit of a difference sometimes.

Lights were a regular point of contention, with older generations typically enforcing more careful standards. Brooke commented: 'Leanne sometimes follows me around the house turning off all the lights,' and Marion 'nagged' her grandchildren to do the same:

The things that we mainly talk about are things like turning out the lights...younger people seem to think, turn on a light in a room and then walk out of the room and leave it on. Whereas when I grew up, you turned the light off.

By living in the same dwelling as her grandchildren, Marion felt that 'we've got a lot of influence over the things that they do and the way that they think... They do get nagged a bit.' Wendy's mother exerted a similar influence:

Wendy: When we go downstairs, Mum is like, 'Turn that light off.'

Wes [Wendy's husband]: Yeah and, 'Can you turn the front porch light off?'

Wendy: Yeah, and 'Go turn that light off'. If I leave a light on she'll say something, so she's always been aware of that, but I think that would be more from a financial perspective, because she was a single mum for a long time. But it has the spin-off of being environmental as well.

Wendy also noted that her mother would be annoyed if they used the clothes dryer: 'Mum likes to hang things out on the line, just from a money perspective, not using electricity.' Opportunities for the intergenerational transfer of skills were also apparent, as in Brooke and Leanne's conversation about a vegetable garden:

Leanne: I've often thought about putting a vegie patch...but it's a lot of hard work...the old knees are not as good as they used to be, you know with bending over...I've done it before so I could do it again. 
Brooke: Yeah that's the difference, I wouldn't know how to start a vegie patch.

Leanne: I could show you...

Brooke: Yeah definitely...I work at Bunnings [home depot store] so we could go get all the stuff from there...I'm always curious to how they get things to grow at different times of the year...but I've never gone out and read about it to grow my own one [vegie garden].

Previous studies have also identified the potential for children and young people to transfer environmental values and knowledge within the home - to act as 'Trojan horses' for more environmentally sustainable lifestyles (Collins and Hitchings 2012: 195; see also Ballantyne et al. 2006; Larsson et al. 2010). Hadfield-Hill (2013: 356) noted that young people, armed with environmental knowledge, 'are in the ideal position to extend the environmental agenda beyond the confines of the classroom, to homes and the wider community.' Yet there was limited evidence of upwards knowledge-transfer amongst our multigenerational family households. In Nathan's instance, this was because he and his wife did not feel comfortable criticising his parents. He and his wife discussed the folly of his parents' decision to use two old and inefficient fridges, but did not pass on this knowledge:

Nathan: The fridge...is close to thirty years old...the freezer is in the garage, and they've also got a bar fridge for the drinks. My wife thought it was silly because they were using up all that electricity when you could just buy a big one...

Interviewer: Did she ever say anything or question that when you were living there?

Nathan: No...although their electricity bill could probably be halved...If they said, 'What do you think?', she would probably tell them that having one fridge would be better, but she would never offer her opinion unsolicited...It's just a matter of respect for somebody. She wouldn't walk into a room and say, 'No you've got too many fridges, get rid of them'...I don't do it either. If my parents were complaining about their electricity bill, I would say, 'Well you know you've got a fridge here, do you really need it, because it is just Dad's beers, you don't need 20 bottles of cold beer all at once, you only need one cold beer...'

Michael was the most obvious example of a 'Trojan horse' amongst our sample of interviewees. He reported trying (mostly unsuccessfully) to convince his parents of anthropogenic climate change. He also tried to encourage them to replace their lawn with a food garden, to purchase furniture from op shops, and to install an 'environmental toilet.' 
It's hard to teach an old dog new tricks. It takes persistence, I had a massive argument with my dad the other day about climate change and whether it was happening or not, and so I brought all this information that I had from the University...he's refusing to read little articles that I bring back...So I'm going to keep leaving things around. I think it's important because there is a lot of information out there that he needs to know. He's very environmentally conscious, he knows to recycle...and cut down water use. He's installing solar panels, but he thinks that this climate change thing is a natural occurrence... I think he needs to know [about anthropogenic climate change], and it's my little goal to convert him across to this...It will take time.

Michael also took his parents to visit an environmentally sustainable house in Port Kembla, south of Wollongong:

[M]y mum loved it, being from a Filipino background where they grew everything, like this whole backyard was overgrown with fruit and vegetables...These people are awesome and there is another one in Unanderra, similar size to my parents' backyard, with fruit in one section and vegies in another section...one of the guys that takes you around there, picked up some grass off the ground and said, 'Can you eat this? Why have grass then?' Grass is like this manicured little thing, so instead of having grass that you have to cut every fortnight you could just plant vegies and trees and these are things you can reuse and eat. And my dad has actually really considered it, because he understands that cutting the grass is an absolute mission and having little dirt paths that go around fruit trees and vegie gardens in the backyard, like a maze of stuff, is just a more wonderful thing than having manicured grass (emphasis added).

Michael conceded that he had not yet won such battles: 'There's a lot more education that needs to go through my parents,' but he was admirably persistent.

\section{Multigenerational Family Households: Mitigating Environmental Harm, Coping with Environmental Calamity}

In this chapter, we have drawn attention to multigenerational family households as sites with the potential to foster a range of environmental benefits: innate, inadvertent and intentional. These larger-than-average households reduce per capita resource consumption through 
economies of scale, and through reduced demand for new dwellings and land for development. Multigenerational family households can achieve such sustainability gains without even trying to be 'green.' Our own research has added insights on the types of sharing (of space, stuff and knowledge) that occur in the everyday lives of multigenerational family households. The households involved in our study enacted a range of environmentally-beneficial practices - oftentimes inadvertently, through decisions, behaviours and values which they made based on caring and/or financial imperatives. Multigenerational family living undoubtedly provides opportunities to mitigate environmental harm - to reduce resource consumption and waste. As shown throughout this chapter, such living arrangements also foster intergenerational learning around environmentally beneficial practices.

Such insights are critical to attempts to rethink housing, the fabric of urban living, and the shifting nature of families (Klocker and Gibson 2013). In closing, though, we want to also suggest that multigenerational family living provides more than sheer quantitative reductions in resource use and carbon footprints (something that requires further, ongoing monitoring and research). Qualitatively, multigenerational living contributes to everyday resilience, to capacities to care for relatives as they age, and to the strengthening of intergenerational knowledge exchanges. In short, it enables families to pool resources and to cope with disruption. In this regard, multigenerational family households also provide an underexplored resource for responding to the kinds of environmental extremity and more frequent disasters that climate scientists now predict as inevitable (Solomon et al. 2009).

Climate change projections for the Illawarra region, where our study took place, anticipate that all temperature variables (average, maximum and minimum temperatures) will increase in the near future (2020-2039) (Office of Environment and Heritage 2014). Studies of heatwave mortality in Europe and the US have shown that people who live alone, and are socially isolated, are at greater risk of death - with particular attention being drawn to the elderly (Klinenberg 2002; Naughton et al. 2002). Kovats and Ebi (2006) noted the risk of people who live alone dying during a heatwave - before their health status comes to the attention of others. The care within family networks enabled by proximity in multigenerational family households will likely prove useful as societies adjust to a climatechanging world. Further, it is now clear that transformational adaptation - including in the domestic sphere - will be necessary under potentially four degrees of warming (Stafford Smith et al. 2011). As Gibson et al. (2015: 416) have argued, the 'resources for survival are 
ultimately social and therefore compel greater scrutiny of...household life.' Household sustainability practices (including the inadvertent ones) may need to be rethought as survival skills (Gibson et al. 2015). The frugality of Nathan's father, Leanne's food growing skills, and Michael's steady efforts to encourage his family to live differently, may have implications beyond identifiable reductions in resource use and carbon footprints. By pooling family members' financial resources, by bringing diverse sets of skills and knowledge under one roof, and by ensuring that vulnerable family members - such as the elderly and young are cared for, multigenerational family households may yet prove an important adaptive resource.

\section{References}

Arbués, F, Villanúa, I and Barberán, R 2010, 'Household size and residential water demand: an empirical approach', Agricultural and Resource Economics, vol. 54, no. 1, pp. 61-80.

Askew, L and McGuirk, P 2004, 'Watering the suburbs: distinction, conformity and the suburban garden', Australian Geographer, vol. 35, no. 1, pp. 17-37.

Australian Bureau of Statistics 2010, Australian Social Trends December 2010. Australian Households: The Future, Australian Bureau of Statistics, Canberra.

Australian Bureau of Statistics 2012, 2011 Census QuickStats - Australia, Australian Bureau of Statistics, Canberra.

Autio, M, Heiskanen, E and Heinonen, V 2009, 'Narratives of 'green' consumers: the antihero, the environmental hero and the anarchist', Journal of Consumer Behaviour, vol. 8, pp. 40-53.

Ballantyne, R, Fien, J and Packer, J 2001, 'Programme effectiveness in facilitating intergenerational influence in environmental education: lessons from the field', Journal of Environmental Education, vol. 32, no. 4, pp. 8-15.

Bentley, M, Fien, J and Neil, C 2004, Sustainable Consumption: Young Australians as Agents of Change, Department of Family and Community Services, Canberra.

Berners-Lee, M 2010, How Bad are Bananas? The Carbon Footprint of Nearly Everything, Profile Books, London. 
Blunt, A 2005, 'Cultural geography: cultural geographies of home', Progress in Human Geography, vol. 29, pp. 505-515.

Büttner, T and Grübler, A 1995, 'The birth of a 'green' generation? Generational dynamics of resource consumption patterns', Technological Forecast and Social Change, vol. 50, pp. $113-134$.

Collins, R and Hitchings, R 2012, 'A tale of two teens: disciplinary boundaries and geographical opportunities in youth consumption and sustainability research', Area, vol. 44, no. 2, pp. 193-199.

Evans, D 2011, 'Thrifty, green or frugal: reflections on sustainable consumption in a changing economic climate', Geoforum, vol. 42, no. 5, pp. 550-557.

Gibson, C, Waitt, G, Head, L and Gill, N 2011, 'Is it easy being green? On the dilemmas of material cultures of household sustainability', in R Lane and A Gorman-Murray (eds), Material geographies of household sustainability, Ashgate, Aldershot, pp. 19-34.

Gibson, C, Farbotko, C, Gill, N, Head, L and Waitt, G 2013, Household sustainability: challenges and dilemmas in everyday life, Edward Elgar, Cheltenham.

Gibson, C, Head, L, and Carr, C 2015, 'From Incremental Change to Radical Disjuncture: Rethinking Everyday Household Sustainability Practices as Survival Skills', Annals of the Association of American Geographers, vol. 105, no. 2, pp. 416-424.

Hadfill-Hill, S 2013, 'Living in a sustainable community: new spaces, new behaviors?', Local Environment: The International Journal of Justice and Sustainability, vol. 18, no. 3, pp. 354-371.

Han, E 2013, 'Urban sprawl eats into Sydney’s farmland', Sydney Morning Herald, 28 July, online, accessed 18 August 2015, < www.smh.com.au/data-point/urban-sprawl-eats-intosydneys-farmland-20130727-2qr6d.html>

Head, L, Farbotko, C, Gibson, C, Gill, N and Waitt, G 2013, 'Zones of friction, zones of traction: the connected household in climate change and sustainability policy', Australasian Journal of Environmental Management, vol. 20, no. 4, pp. 351-362.

Hitchings, R, Collins, R and Day, R 2015, 'Inadvertent environmentalism and the actionvalue opportunity: reflections from studies at both ends of the generational spectrum', Local Environment, vol. 20, no. 3, pp. 369-385. 
Hobson, K 2006, 'Bins, bulbs and shower timers: on the 'techno-ethics' of sustainable living', Ethics, Place and Environment, vol. 9, pp. 317-336.

Hobson, K 2008, 'Reasons to be cheerful: thinking sustainably in a (climate) changing world', Geography Compass, vol. 2, pp. 199-214.

Horne, R, Maller, C and Lane, R 2011, 'Remaking home: the reuse of goods and materials in Australian households', in R Lane and A Gorman-Murray (eds), Material Geographies of Household Sustainability, Ashgate, Aldershot, pp. 89-111.

Independent Pricing and Regulatory Tribunal 2010, 'Household Survey of Electricity, Water and Gas Usage: Sydney, Blue Mountains and the Illawarra', Independent Pricing and Regulatory Tribunal, Sydney.

Jones, I, Higgs, P and Ekerdt, D 2009, Consumption and Generational Change: The Rise of Consumer Lifestyles, Transactions Publishers, New Jersey.

Keilman, N 2003, 'The threat of small households', Nature, vol. 421, pp. 489-490.

Klinenberg, E 2002, Heat wave: a social autopsy of disaster in Chicago. University of Chicago Press, Chicago.

Klocker, N, Gibson, C and Borger, E 2012, 'Living together, but apart: Material geographies of everyday sustainability in extended family households', Environment and Planning A, vol. 44, no. 9, pp. 2240-2259.

Klocker, N and Gibson, C 2013, 'Looking inwards: extended family living as an urban consolidation alternative', Planning Theory and Practice, vol. 14, no. 4, pp. 555-559.

Kollmuss, A and Agyeman, J 2002, 'Mind the Gap: Why do people act environmentally and what are the barriers to pro-environmental behavior?' Environmental Education Research, vol. 8 , no. 3, pp. 239-260.

Kovats, R and Ebi, K 2006, 'Heatwaves and public health in Europe', European Journal of Public Health, vol. 16, no. 6, pp. 592-599.

Krueger, R and Agyeman, J 2005, 'Sustainability schizophrenia or actually existing sustainabilities? Towards a broader understanding of the politics and promise of local sustainability in the USA', Geoforum, vol. 36, no. 4, pp. 410-417.

Lane, R and Gorman-Murray, A (eds) 2011, Material Geographies of Household Sustainability, Ashgate, Aldershot. 
Larsson, B, Andersson, M, and Osbeck, C 2010, 'Bringing environmentalism home: Children's influence on family consumption in the Nordic countries and beyond', Childhood, vol. 17, no. 1, pp. 129-147.

Lenzen, M and Murray, S 2001, 'A modified ecological footprint method and its application to Australia', Ecological Economics, vol. 37, pp. 229-255.

Lenzen, M, Dey, C and Foran, B 2004, 'Energy requirements of Sydney households', Ecological Economics, vol. 49, pp. 375-399.

Liu, J, Linderman, M, Ouyang, A, An, L, Yang, J and Zhang, H 2001, 'Ecological degradation in protected areas: The case of Wolong Nature Reserve for giant pandas', Science, vol. 292, pp. 98-101.

Liu, J, Daily, G, Ehrlich, P and Luck G 2003, 'Effects of household dynamics on resource consumption and biodiversity', Nature, vol. 421, pp. 530-533.

Liu, J and Diamond, J 2005, 'China's environment in a globalizing world', Nature, vol. 435, pp. 1179-1186.

Maller, C 2011, 'Practices involving energy and water consumption in migrant households', in P Newton (ed.), Urban Consumption, CSIRO, Canberra, pp. 237-250.

Naughton, M, Henderson, A and Mirabelli, M 2002, 'Heat related mortality during a 1999 heatwave in Chicago', American Journal of Preventive Medicine, vol. 22, pp. 221-227.

Nicholls, S and Moore, M 2011, 'Green light for urban sprawl' Sydney Morning Herald, 8 February, accessed 3 December 2015, < www.smh.com.au/nsw/green-light-for-urbansprawl-20110207-1ak8x.html>

Office of Environment and Heritage 2014, Illawarra Climate change snapshot, NSW Office of Environment and Heritage, Sydney.

O’Neill, B and Chen, B 2002, 'Demographic determinants of energy use in the United States', Population and Development Review, vol. 28, pp. 53-88.

O'Neill, P and James, S 2014, 'Feeding Sydney: assessing the importance of the city's periurban farms', in B Maheshwari, R Purohit, H Malano, V Singh and P Amerasinghe (eds), The Security of Water, Food, Energy and Liveability of Cities, Springer, Chapter 18, pp. 243-256. 
Percy-Smith, B and Burns, D 2013, 'Exploring the role of children and young people as agents of change in sustainable development', Local Environment, vol. 18, no. 3, pp. $323-$ 339.

Reid, L, Sutton, P and Hunter, C 2010, 'Theorizing the meso level: the household as a crucible of pro-environmental behaviour', Progress in Human Geography, vol. 34, no. 3, pp. 309-327.

Shove, E 2003, Comfort, Cleanliness and Convenience: The Social Organization of Normality, Berg, Oxford.

Smith, B 2015, 'Biodiversity under threat as Melbourne's grasslands become suburbs', Sydney Morning Herald, 27 May, accessed 18 August 2015, $<$ www.smh.com.au/technology/sci-tech/biodiversity-under-threat-as-melbournesgrasslands-become-suburbs-20150526-gh9v16.html>

Solomon, S, Plattner, GK, Knutti, R and Friedlingstein, P 2009, 'Irreversible climate change due to carbon dioxide emissions', Proceedings of the National Academy of Sciences, vol. 106, pp. 1704-09.

Stafford Smith, M, Horrocks, L, Harvey, A and Hamilton, C 2011, 'Rethinking adaptation for a $4^{\circ} \mathrm{C}$ world', Philosophical Transactions of the Royal Society A: Mathematical, Physical and Engineering Sciences, vol. 369, no. 1934, pp. 196-216

Stanes, E, Klocker, N and Gibson, C 2015, 'Young adult households and domestic sustainabilities', Geoforum, vol. 65, pp. 46-58.

Stanes, E and Klocker, N 2016, 'Young people in the Global North: environmental heroes or pleasure-seeking consumers?', in N Ansell and N Klocker (eds), Global Issues, Change and Threat, vol. 8 of Skelton, T. (ed.) Geographies of Children and Young People, Springer, Singapore.

Strengers, Y and Maller, C 2012, 'Materialising energy and water resources in everyday practices: Insights for securing supply systems', Global Environmental Change, vol. 22, no. 3, pp. 754-63.

Tolia-Kelly, D 2004, 'Materialising post-colonial geographies: examining the textual landscapes of migration in the South Asian home', Geoforum, vol. 35, no. 6, pp. 675-888.

Vanderbeck, R 2007, 'Intergenerational geographies: age relations, segregation and reengagements', Geography Compass, vol. 1, no. 2, pp. 200-221. 
Waitt, G, Caputi, P, Gibson, C, Farbotko, C, Gill, N and Stanes, E 2012, 'Sustainable household capability: which household are doing the work of environmental sustainability?', Australian Geographer, vol. 43, no. 1, pp. 51-74.

Wright, J, Osman, P and Ashworth, P 2009, The CSIRO Home Energy Saving Handbook, Pan Macmillan, Sydney.

Yu, E and Liu, J 2007, 'Environmental impacts of divorce', Proceedings of the National Academy of Sciences, vol. 104, no. 51, pp. 20629-20634. 